\title{
Perilaku Komunikasi Organisasi dalam Sosialisasi Program Kerja di Desa Wonorejo Kecamatan Gondangrejo Kabupaten Karanganyar
}

\section{Organizational Communication Behavior in Work Program Socialization in Wonorejo Village, Gondangrejo District, Karanganyar Regency}

\author{
A. Anditha Sari* \& Jahid Syaifullah \\ Program Studi Komunikasi Massa, Politeknik Indonusa, Surakarta, Indonesia \\ Diterima: September 2019: Disetujui: Oktober 2019; Dipublish: Oktober 2019 \\ *Coresponding Email: andhita@poltekindonusa.ac.id
}

\begin{abstract}
Abstrak
Tujuan dalam penelitian ini adalah gambaran perilaku komunikasi organisasi yang terjadi pada pelaksanaan sosialisasi program kerja di Desa Wonorejo Kecamatan Gondangrejo Kabupaten Karanganyar. Dari gambaran tersebut penulis menarik pola komunikasi yang terbentuk dalam komunikasi organisasi tersebut serta keberhasilan perilaku komunikasi yang diterapkan terhadap kepuasan masyarakat dan keberlangsungan pembangunan. Perilaku komunikasi organisasi merupakan kajian dalam penelitian ini. Salah satu perilaku komunikasi organisasi di dalam pemerintahan nampak di dalam pelaksanaan sosialisasi program kerja kepada masyarakat. Penelitian yang dilaksanakan di Desa Wonorejo Kecamatan Gondangrejo Kabupaten Karanganyar ini juga untuk menelusuri tingkat persepsi warga dalam program kerja desa yang telah di rencanakan, serta bagaimana tingkat dan wujud partisipasi warga dalam menyongsong program pembangunan. Subyek penelitian adalah perangkat desa dan tokoh masyarakat di Desa Wonorejo Kecamatan Gondangrejo Kabupaten Karanganyar. Teknik pengumpulan data menggunakan wawancara, observasi, dan dokumentasi. Data-data yang digunakan dianalisis menggunakan analisis deskriptif, sedangkan kevalidan data diuji dengan model triangulasi. Kesimpulannya perilaku komunikasi organisasi mengacu kepada fungsi komunikasi dalam organisasi bahwa terdapat empat fungsi dalam kinerja organisasi, yakni fungsi informatif, fungsi regulatif, fungsi persuasif, dan fungsi integratif.
\end{abstract}

Kata Kunci : Perilaku komunikasi, komunikasi organisasi, pembangunan desa

\section{Abstract}

The main purpose in this research is the picture of organizational communication behavior that occurs in the implementation of work program socialization in Wonorejo village Gondangrejo districts karanganyar district. From the description of the authors draw the communication patterns formed in the organization's communication and the success of communication behavior that is applied to the satisfaction of the community and the sustainability of development. Organizational communication behavior is a case in this study.One of the behavior of organizational communication in the government appears in the implementation of socialization of work programs to the community.Research conducted in Wonorejo village Gondangrejo districts karanganyar district also to track the perceptions of the people in the village work program that has been planned,and and how the level and form of citizen participation in welcoming the development program. The subjects of research are village apparatus and community leaders in Wonorejo village Gondangrejo districts karanganyar district.Techniques of collecting data using interviews, observation, and documentation. The data used were analyzed using descriptive analysis, whereas the validity of the data was tested by triangulation model. In conclusion, organizational communication behavior refers to the communication function within the organization that there are four functions in organizational performance, namely informative function, regulative function, persuasive function, and integrative function.

Keyword: communication behavior, organizational communication, rural development

How to Cite: Sari, A.A. \& Syaifullah, J. (2019). Perilaku Komunikasi Organisasi dalam Sosialisasi Program Kerja di Desa Wonorejo Kecamatan Gondangrejo Kabupaten Karanganyar . JURNAL SIMBOLIKA: Research and Learning in Comunication Study. 5 (2): 132-144 


\section{PENDAHULUAN}

Pembangunan nasional merupakan proses pembangunan manusia Indonesia seutuhnya dan pembangunan masyarakat Indonesia seluruhnya melalui Pancasila sebagai dasar, tujuan, dan pedomannya. Dari amanat tersebut disadari bahwa pembangunan nasional bukan sematamata proses ekonomi, tetapi penjelmaan pula dari proses perubahan politik, sosial, dan budaya di dalamnya. Pembangunan nasional merupakan cerminan kehendak terus-menerus meningkatkan kesejahteraan dan kemakmuran rakyat Indonesia secara adil dan merata, serta mengembangkan kehidupan masyarakat dan penyelenggaraan negara yang maju dan demokratis berdasarkan Pancasila.

Sistem pembangunan Indonesia ditandai proses pembangunan yang manajemennya dilakukan oleh pemerintah pusat dan pembangunan daerah yang proses pembangunannya dilakukan pemerintah daerah. Pembangunan peningkatan pelayanan, pemberdayaan, dan peranan serta masyarakat dalam berbagai sektor untuk mewujudkan kesejahteraan masyarakat secara efektif dan efisien dalam sistem NKRI. Dalam Undang-Undang Nomor 23 Tahun 2014 menjadi acuan Pemerintah Daerah bergerak memenuhi kewajiban dalam melakukan segala kegiatan atau program kerja yang telah diatur sesuai hukum dari Pemerintah Pusat ke daerah.

Menurut Undang-Undang Nomor 6 Tahun 2014 Desa adalah kesatuan masyarakat hukum yang memiliki batas wilayah yang berwenang untuk mengatur dan mengurus urusan pemerintahan, kepentingan masyarakat setempat berdasarkan prakarsa masyarakat, hak asal usul, dan atau hak tradisional yang diakui dan dihormati dalam sistem pemerintahan Negara Kesatuan Republik Indonesia.Desa juga merupakan daerah politik yang otonom. Fungsi kecamatan dalam konteks ini adalah sekedar menjalankan fungsi administratif dan koordinatif di wilayah kecamatan, sesuai dengan status kecamatan yang tidak lagi menjadi sebuah wilayah kekuasaan melainkan sekedar sebagai perpanjangan dari kabupaten. Di desa, pembangunan ditujukan untuk kemajuan desa dan berdampak pada kesejahteraan masyarakatnya. Pembangunan desa harus dapat melihat apa saja yang menjadi potensi dari desa yang bisa diangkat dan dijadikan suatu peluang untuk desa agar desa tersebut dapat memiliki keunggulan yang berbeda dengan desa lainnya meskipun desa-desa tersebut berada didalam suatu kecamatan yang sama. Pembangunan di desa dapat meliputi pembangunan dalam bidang petanian, 
A. Anditha Sari \& Jahid Syaifullah, Perilaku Komunikasi Organisasi dalam Sosialisasi Program Kerja

perternakan, perkebunan atau lain sebagainya sesuai dengan potensi-potensi yang ada di setiap daerah desa tersebut.

Daerah pedesaan mempunyai fungsi dan peranan yang sangat penting, yaitu seperti menghasilkan berbagai jenis komoditas pertanian (padi, hasil perkebunan, dan yang lainnya) untuk memenuhi kebutuhan penduduk perkotaan, sebagai bahan baku untuk industri dan sebagian lagi untuk ekspor. Oleh karena itu upaya pembangunan pedesaan haruslah menjadi salah satu prioritas dan harus mendapatkan perhatian yang lebih pada saat ini maupun di masa mendatang. Pada saat melaksanakan pembangunan di desa, desa sering mengalami hambatan dan kendala yang tidak ringan dari segi geografis, topografi, demografis, ketersediaan sarana dan prasarana, kelemahan akses terhadap informasi dan modal pasar, partisipasi masyarakat yang belum proaktif, dan masih banyak kelemahan fungsi organisasional dan fungsional-operasional lainnya.

Komunikasi sebagai elemen dasar perilaku organisasi ini merupakan wujud eratnya kaitan antara komunikasi dan organisasi. Komunikasi organisasi adalah suatu penampakan dan persepsi pesan atau informasi di dalam unit-unit komunikasi yang merupakan bagian dari suatu organisasi tertentu. Di dalam organisasi pada umumnya terdapat unitunit komunikasi dalam beberapa hubungan hierarkis antara yang satu dengan yang lainnya juga berfungsi dalam suatu lingkungan tertentu.

Kaitan antara komunikasi dan organisasi dikemukakan oleh William V. Hanney dalam Effendy (1981) yang menyatakan bahwa organisasi terdiri dari sejumlah orang; ia melibatkan keadaan saling tergantung; ketergantungan memerlukan koordinasi; koordinasi mensyaratkan komunikasi. Karenanya, komunikasi merupakan sine qua non bagi organisasi. Bagi organisasi, komunikasi berperan penting dalam membina manusia-manusia di dalam organisasi dan membina perilaku organisasi di antara para anggota organisasi atau karyawan. Tujuan utama perilaku organisasi adalah untuk menggambarkan secara sistematis bagaimana orang-orang berperilaku dalam beragam kondisi, untuk memahami mengapa mereka berperilaku seperti itu.

$$
\text { Pembangunan desa dikaji }
$$

menggunakan pendekatan partisipatif yang diartikan pembangunan dilakukan dari bawah (bottom-up development), dimana masyarakat terlibat langsung dan mengambil peran serta dalam pembangunan. Dalam menciptakan ketatapemerintahan yang optimal, maka dikenallah istilah dengan good governance. 
Lingkungan ketatapemerintahan yang optimal diyakini harus memiliki elemenelemen yang saling berkolaborasi secara sinergis dan menciptakan keserasian sepanjang masa. Elemen pemerintahan desa, masyarakat desa dan pihak swasta harus memiliki keinginan kuat untuk berasama-sama membangun desa.

Peran serta masyarakat dalam proses pembangunan sangat menentukan tingkat keberhasilan pembangunan desa. Kemampuan masyarakat untuk memberikan andil dalam pembangunan dipengaruhi oleh berbagi faktor. Salah satu faktor yang mempengaruhi andil masyarakat dalam pembangunan desa adalah tingkat keterbukaan perangkat desa terhadap program desa yang direncanakan. Penelitian tersebut menunjukan bahwa salah satu faktor yang menghambat terlaksananya keterbukaan program kerja oleh perangkat desa adalah masih rendahnya tingkat pendidikan, baik aparatur pemerintah desa maupun masyarakat, rendahnya tingkat pendidikan berdampak pada rendahnya wawasan dan pengetahuan masyarakat sehingga menyulitkan pemerintah desa untuk mengidentifikasikan masalah desa sebagai bahan pembuatan kebijakan dan program pembangunan, rendahnya partisipasi masyarakat dalam pembuatan kebijakan dan program pembangunan desa, dan lemahnya akses pemerintah desa pada ranah jaringan kelembagaan diatasnya maupun jaringan social lainnya.

Hambatan-hambatan dalam pelaksanaan komunikasi pembangunan juga dihadapi oleh pemerintah Desa Wonorejo Kecamatan Gondangrejo Kabupaten Karanganyar. Profil topografi desa dengan wilayah yang cukup luas dengan jumlah sembilan dusun membuat proses komunikasi di Desa Wonorejo menjadi hal yang harus dicermati dalam upaya meningkatkan percepatan pembangunan. Pelaksanaan program bantuan desa yang digulirkan oleh pemerintah baik pemerintah pusat maupun daerah menuntut adanya partisipasi masyarakat baik dalam hal perencanaan maupun pelaksanaannya. Tuntutan adanya partisipasi masyarakat agar suatu program bantuan dapat terlaksana, maka komunikasi organisasi desa baik antara pimpinan desa dengan perangkat desa maupun perangkat desa dengan masyarakat menjadi salah satu faktor yang penting untuk mempercepat proses pembangunan.

Berdasarkan latar belakang dan permasalahan yang telah diutarakan diatas maka tujuan dalam penelitian ini adalah : untuk mengetahui gambaran pola komunikasi organisasi di Desa Wonorejo Kecamatan Gondangrejo Kabupaten 
Karanganyar dalam pemberdayaan masyarakat dalam proses pembangunan serta mengetahui persepsi masyarakat terhadap pola komunikasi organisasi yang dijalankan pemerintah Desa Wonorejo Kecamatan Gondangrejo Kabupaten Karanganyar dalam pemberdayaan masyarakat dalam proses pembangunan.

\section{METODE PENELITIAN}

Penelitian ini menggunakan penelitian kualitatif. Pawito (2007) menjelaskan bahwa penelitian kualitatif berfokus pada mengemukakan gambaran dan atau pemahaman mengenai bagaimana dan mengapa suatu gejala atau realitas komunikasi terjadi. Karena hanya memberikan gambaran mengenai sebuah fenomena, maka metode penelitian yang digunakan adalah deskriptif. Penelitian deskriptif oleh Sugiyono (2010) merupakan penelitian yang dilakukan untuk mengetahui nilai variabel mandiri, baik satu variabel atau lebih (independen) tanpa membuat perbandingan atau menghubungkan dengan variabel lain.

Data primer dalam penelitian ini diambil dari hasil wawancara (interview) dengan informan dalam penelitian. Informan diambil menggunakan tehnik purposive sampling, Purposive sampling menurut Danim (2004) merupakan penentuan sampel dengan mempertimbangkan kriteria-kriteria tertentu yang telah dibuat terhadap obyek yang sesuai dengan tujuan penelitian. Dalam penelitian ini, penulis mengambil sampel penelitian adalah perangkat desa dan tokoh masyarakat di Desa Wonorejo Kecamatan Gondangrejo Kabupaten Karanganyar.

Data sekuder diambil dari dokumen yang berasal dari profil pelaksanaan program pembangunan melibatkan masyarakat serta yang membutuhkan partisipasi dari masyarakat. Gambaran pola komunikasi yang dianalisis adalah terhitung dari Januari-September 2017. Penyajian data dilakukan dengan menyimpulkan hasil data berupa wawancara dari nara sumber.

\section{HASIL DAN PEMBAHASAN}

Penelitian ini merupakan penelitian deskriptif yang bertujuan untuk menggambarkan pola komunikasi organisasi di Desa Wonorejo Kecamatan Gondangrejo Kabupaten Karanganyar dalam pemberdayaan masyarakat dalam proses pembangunan dan untuk mendeskripsikan persepsi masyarakat terhadap pola komunikasi organisasi yang dijalankan pemerintah Desa Wonorejo Kecamatan Gondangrejo Kabupaten Karanganyar dalam pemberdayaan masyarakat dalam proses pembangunan. 
Pola Komunikasi Organisasi Di Desa Wonorejo Kecamatan Gondangrejo Kabupaten Karanganyar

Pola komunikasi organisasi dalam penelitian ini adalah pola pemerintah desa dalam mengkomunikasikan programprogram dan kebijakan desa kepada masyarakat. Komunikasi yang dilakukan bertujuan agar masyarakat secara luas mengetahui program-program dan kebijakan desa sehingga proses pelaksanan program desa dapat berjalan dengan baik khususnya mendapat dukungan dari masyarakat.

Identifikasi pola komunikasi organisasi di Desa Wonorejo Kecamatan Gondangrejo Kabupaten Karanganyar dijabarkan melalui jenis program yang disosialiasikan, langkah-langkah sosialisasi dan pihak-pihak yang dilibatkan, faktorfaktor yang mendukung proses sosialisasi, dan hambatan-hambatan yang muncul dalam proses sosialisasi.

Hasil wawancara dengan Kepala Desa Wonorejo menyebutkan bahwa programprogram yang biasanya disosialisasikan kepada masyarakat meliputi: 1) Program peningkatan kualitas pelayanan umum kepada masyarakat yaitu E-Ktp, kartu keluarga, surat kelahiran, surat kematian, surat pengantar pembuatan surat keterangan catatan kepolisian (SKCK) dan surat keterangan tidak mampu. 2) Program peningkatan ketertiban dan keamanan desa yaitu ronda malam lingkungan RT, pemeliharaan lampu penerangan jalan, penambahan dan pemeliharaan Poskamling. 3) Program peningkatan fasilitas dan pemberdayaan potensi ekonomi kerakyatan melalui sektor pertanian melalui pembangunan jalan usaha tani, pembangunan jalan dusun, dan pembangunan jalan desa pelatihan budidaya pertanian, ternak dan perkebunan.

Berbagai program yang telah dijabarkan di atas kemudian dilakukan sosialisasi oleh perangkat desa dalam Musyawarah Rencana Pembangunan Desa (Musrenbangdes) Desa Wonorejo yang melibatkan semua komponen pemerintah desa khususnya kepala-kepala wilayah.

Undang-Undang nomor 6 Tahun 2014 bahwa Musrenbang Desa adalah forum musyawarah tahunan para pemangku kepentingan (stakeholder) desa untuk menyepakati Rencana Kerja Pembangunan Desa (RKP) tahun anggaran yang direncanakan. Musrenbang Desa dilaksanakan setiap bulan Januari dengan mengacu pada RPJM desa. Setiap desa diamanatkan untuk menyusun dokumen rencana 5 tahunan yaitu RPJM Desa dan dokumen rencana tahunan yaitu RKP Desa.

Seperti Kepala Dusun (Bayan), ketua rukun warga (RW) dan ketua rukun tetangga (RT) serta beberapa tokoh 
masyarakat baik yang termasuk dalam anggota BPD maupun beberapa tokoh masyarakat yang dianggap mewakili aspirasi masyarakat. Hal tersebut sebagaimana dikemukakan oleh hasil wawancara dengan dengan Bapak Kepala Dusun (Bayan) Jetak sebagai berikut.

"Dari pihak kelurahan ada yang dinamakan dengan Musrenbangdes yang diadakan sebelum akhir tahun, karena akan dianggarkan untuk anggaran tahun selanjutnya. di dalam Musrenbangdes nantinya akan banyak pemaparan dari program masing- masing wilayah. kemudian akan didiskusikan apakah dana terlalu besar sehingga perlu dikurangi atau sebaliknya. Selain itu dari pihak kelurahan juga secara transparan melaporkan hasil programnya, seperti pemaparan dana hibah desa yang dilaporkan melalui pamfleat atau spanduk sehingga bisa dibaca oleh masyarakat"

Berdasarkan hasil wawancara tersebut menunjukkan bahwa proses sosialisasi program-program desa didahului dengan proses musyawarah desa (Musrenbangdes) yang melibatkan hampir semua komponen masyarakat. Selanjutnya hasil-hasil yang diperoleh dalam Musrenbangdes tersebut disampaikan kepada masyarakat melalui pamlet dan spanduk sehingga mudah diketahui oleh masyarakat.
Proses sosialisasi program desa, tidak hanya terhadap program-program atau isu yang bersifat regular namun juga terhadap program-program yang bersifat mendesak di luar program RPJM Desa. Sebagai contoh program jalan tol di wilayah Desa Wonorejo dan program tanah hibah. Di kedua program tersebut pemerintah desa bersifat netral dan berperan sebagai mediator dalam proses penyelesaiannya.

Dalam proses perselisihan ganti rugi jalan tol, pemerintah desa berperan sebagai pihak yang membantu masyarakat melakukan klaim terhadap adanya perbedaan antara PPATK sebagai pihak yang mengukur dampak kerugian yang dialami oleh masyarakat. Proses penyelesaian dampak pembangunan jalan tol yang terjadi di Desa Wonorejo memang pada prosesnya terdapat masyarakat yang pro dan kontra, artinya setuju dengan besarnya ganti rugi yang diterima dan ada pula yang menolak terhadap ganti rugi yang diterima. Pada prosesnya pemerintah desa mengakomodir kondisi yang terjadi tersebut dan selanjutnya membantu masyarakat untuk melakukan klaim kepada pihak-pihak yang berkompeten. Hal tersebut sebagaimana dikemukakan dari hasil wawancara dengan bapak Kadus Jetak sebagai berikut.

“Terhadap program tol, dari pihak PPATK akan melakukan pendataan 
langsung kepada masyarakat di setiap wilayah. di dalam proses pendataan ada yang menolak karena tanaman yang belum ada, halaman yang hilang. nanti dari pihak pendataan akan dilaporkan siapa saja yang menolak dan menerima."

Peran pemerintah desa sebagai mediator dan komunikator ditunjukkan pula pada proses sosialisasi program hibah desa. Pada pelaksanaan program hibah, pemerintah desa terlebih dahulu melakukan sosialisasi kepada masyarakat melalui kepala dusun (Bayan). Proses pelaksanaan program hibah diserahkan kepada masyarakat, sedangkan Pemerintah desa khususnya Kepala Desa dalam program ini berperan sebagai pihak yang melakukan evaluasi kelayakan hasil kegiatan. Hal tersebut sebagaimana dikemukakan oleh bapak Kadus Wonorejo sebagai berikut.,

"Sebelum dilaksanakan program hibah, ada sosialisasi lewat pak Kadus, untuk pelaksanaan diserahkan kepada masyarakat, pak Kades netral sehingga tidak berperan langsung dalam pelaksanaan program desa. Setelah terlaksana dari pak Kades akan menindaklanjuti apakah pembangunan berhasil atau tidak, berjalan atau tidak atau ada kecurangan atau tidak yang kemudian akan disampaikan ke tim pelaksana dari pihak kelurahan."
Dalam proses sosialisasi program sejauh ini tidak ditemui adanya hambatan yang bersifat mendasar. Hambatanhambatan yang dialami umumnya adalah akibat dari adanya kesalahpahaman dalam memahami informasi dari atasan kepada bawahan di Desa, dimana hambatan tersebut segera dapat diatasi ketika dilakukan komunikasi yang lebih baik.Hal tersebut sebagaimana disampaikan oleh bapak Kepala Desa sebagai berikut.

"Kendala yang berasal dari perbedaan individual manusia. Perbedaan persepsi, perbedaan umur, perbedaan keadaan emosi, keterampilan mendengarkan, perbedaan status, pencairan informasi, penyaringan informasi. Kendala yang ditimbulkan oleh iklim psikologis dalam organisasi. Suasana iklim kerja dapat mempengaruhi sikap dan perilaku staf dan efektifitas komunikasi organisasi."

\section{Persepsi Masyarakat terhadap Komunikasi Organisasi yang Dibangun Di Desa Wonorejo Kecamatan Gondangrejo Kabupaten Karanganyar.} Persepsi masyarakat terhadap komunikasi organisasi khususnya terhadap sosialisasi program desa kepada masyarakat secara umum adalah baik. Hal tersebut sebagaimana dikemukakan oleh Kadus Jetak sebagai berikut : 
"Persepsi masyarakat baik dengan adanya berbagai program dan mereka lebih banyak memberikan masukan dalam pelaksanaan program desa. sehingga kerja sama bisa berjalan dengan baik. Selain itu dari pihak kelurahan juga mengadakan pengarahan untuk mengetahui perkembangan dalam pelaksanaan program."

Persepsi yang positif dari masyarakat juga disebabkan oleh faktor kebutuhan masyarakat terhadap program-program yang dicanangkan oleh desa. Hal tersebut dikemukakan oleh Kadus Wonorejo sebagai berikut:

"Masyarakat menanggapi dengan serius dan menerima dengan senang hati. karena sebelum adanya dana desa pelaksanaan pembangunan sangat sulit. Secara strata ekonomi masyarakat Wonorejo banyak yang buruh dan petani sehingga pembangunan akan menjadi sulit jika tidak ditunjang dari pemerintah desa."

Berdasarkan uraian hasil temuan di lapangan di atas maka dapat kita ketahui bahwa proses sosialisasi programprogram desa secara umum telah dituangkan dalam Rencana Pembangunan Jangka Menengah Desa (RPJM-Desa) melalui proses musyawarah pembangunan desa (Musrenbangdes) yang melibatkan semua unsur pemerintah desa mulai dari Kepala Desa, Sekretaris Desa, Kepala
Urusan, Kepala Dusun, Ketua Rukun warga (RW), Ketua Rukun Tetangga (RT), dan unsur tokoh masyarakat yang terwakili dalam Anggota Badan Perwakilan Desa (BPD). Hasil musyawarah yang tertuang dalam RPJM-Desa selanjutnya disampaikan kepada masyarakat desa dengan menempel pamlet-pamlet dan spanduk di beberapa wilayah desa yang mudah diketahui oleh masyarakat, sebagai bentuk pemberitahuan dan sosialisasi programprogram desa yang telah ditetapkan. Pada kasus-kasus khusus, misalnya dampak pembangunan Tol dan hibah tanah, maka pemerintah desa berperan sebagai mediator dan komunikator antara masyarakat yang terkena program dengan pihak-pihak yang berkepentingan dengan program tersebut.

Proses sosialisasi yang telah dilakukan oleh pemerintah desa Wonorejo cukup berhasil oleh pemerintah desa. Beberapa faktor yang mendukung keberhasilan proses sosialisasi sebagaimana dikemukakan oleh Kepala Desa dan Sekretaris Desa Wonorejo antara lain adalah adanya tanggung Jawab pelaku aparatur desa, kehangatan antara pelaku aparatur desa dengan masyarakat, dan dukungan dan sambutan masyarakat. Dari unsur masyarakat yaitu adanya antusiasme dan kekompakan masyarakat dalam proses pembangunan di desa. Hal 
tersebut sebagaimana dikemukakan oleh bapak Kadus Jetak sebagai berikut :

"Partisipasi pembangunan di masyarakat Koordinasi pemerintah desa sebagai penyedia dana pembangunan desa dengan Kadus. Musyawarah mengenai halhal apa saja yang harus dibangun, yang vital dengan masyarakat kemudian dikembalikan di pemerintah desa dan kemudian di saring mana yang bisa dijadikan prioritas. Secara pelaksanaan pekerjaan program kerja masyarakat berperan aktif sehingga menjadi guyub rukun."

Proses sosialisasi program di desa Wonorejo Kecamatan Gondangrejo Kabupaten Karanganyar telah dilaksanakan sesuai Surat Edaran bersama Menteri Negara Perencanaan Pembangunan Nasional/ Kepala Bappenas dan Menteri Dalam Negeri Nomor: 1181/M.PPN/02/2006 perihal "Petunjuk Teknis Penyelenggaraan Musyawarah Perencanaan Pembangunan Tahun 2006". Proses penyusunan dokumen Rencana Pembangunan Jangka Menengah Desa (RPJM-Desa) memerlukan koordinasi antar instansi pemerintah dan partisipasi seluruh pelaku pembangunan tingkat desa, melalui suatu forum yang disebut sebagai Musyawarah Perencanaan Pembangunan atau Musrenbang.
Ditinjau dari ilmu komunikasi, maka proses komunikasi organisasi yang dilakukan oleh aparatur desa Wonorejo meliputi proses komunikasi ke bawah, ke atas, dan horizontal. Proses komunikasi ke bawah adalah bagaimana pemerintah desa menginformasikan program-program desa kepada masyarakat baik melalui aparatur dibawahnya misalnya kepala dusun, maupun secara langsung kepada masyarakat yaitu dengan pemasangan pamlet dan spanduk-spanduk program kerja desa kepada masyarakat.

Proses komunikasi ke atas adalah komunikasi masyarakat melalui perwakilannya pada anggota Badan Perwakilan Desa atau kepada masingmasing ketua masyarakat (Ketua RT dan Ketua RW) juga mengaspirasikan pendapat-pendapat mereka dalam penyusunan program-program desa yang dibahas dalam Musrenbangdes. Proses komunikasi horizontal adalah aparatur desa memberikan kesempatan kepada masyarakat untuk dapat mengelola program-program wilayah melalui musyawarah wilayah, misalnya pada program hibah tanah di wilayah.

Proses komunikasi organisasi yang dilakukan oleh aparatur desa Wonorejo telah memenuhi fungsi-fungsi komunikasi organisasi sebagaimana dikemukakan oleh 
Burhan (2006), antara lain adalah sebagai berikut.

Fungsi informative, dalam organisasi desa berfungsi sebagai penyampai informasi kepada seluruh anggota organisasi. Dalam hal ini aparatur desa telah melakukan penyampaian informasi kepada segenap anggota organisasi desa baik perangkat desa maupun masyarakat. Proses tersebut dilakukan melalui mekanisme Musrenbangdes dan hasilnya disosialisasi kepada masyarakat melalui pembuatan pamlet dan spanduk.

Organisasi desa berfungsi persuasif melalui cara komunikasi pimpinan yang mampu menggerakkan anggotanya dibandingkan dengan memerintah. Fungsi ini ditunjukkan dengan bagaimana aparatur desa menempatkan diri sebagai pihak yang netral dan berperan sebagai evaluator dalam program hibah desa.

Fungsi Integratif, fungsi organisasi melalui pimpinan mampu mendorong anggotanya untuk dapat melaksanakan tugas dengan sebaik-baiknya. Fungsi ini ditunjukkan dengan upaya pemerintah desa untuk aktif melakukan komunikasi pada pelaksanaan program desa, serta aktif melakukan evaluasi dalam setiap tahap pelaksanaan program desa, sehingga tujuan yang ditetapkan dalam setiap program dapat tercapai dengan maksimal.
Fungsi Regulatif, dalam pembagian kerja di dalam organisasi desa sesuai dengan kebutuhan masyarakat dan kemampuan personal pegawai pemerintah yag menunjang pembangunan desa. Pembagian kerja desa wonorejo di sektor formal terdiri dari lurah (Kepala Desa), Sekretaris desa, Kepala urusan Agama, Kepala Urusan Kesejahteraan Rakyat, Kepala Urusan Pembangunan, Kepala Dusun, hingga jajaran RT. Di sektor non formal memiliki pengurus masing-masing kelompok baik itu kelompok tani, kelompok usaha desa, hingga sampai kepada pengurus LPMP dan LPMD.

\section{SIMPULAN}

Proses sosialisasi program di desa Wonorejo Kecamatan Gondangrejo Kabupaten Karanganyar telah dilakukan menggunakan media musyawarah. Proses komunikasi organisasi yang dilakukan oleh aparatur desa Wonorejo memenuhi fungsifungsi komunikasi organisasi yakni informatif dengan memberikan informasi kepada masyarakat terkait dengan program hibah pembangunan desa, sosialisasi layanan pemerintah desa, hingga sosialisasi mengenai tahapan penggantian tanah warga yang terdampak pembangunan tol. Fungsi Regulatif dengan adanya pemerintah desa wonorejo yang telah memberikan tugas kepada setiap 
anggota petugas kelurahan sesuai dengan kebutuhan warga. Fungsi Persuasif yang telah dilaksanakan dengan memberikan edukasi kepada warga yang terdampak tol serta memberikan jalan tengah dalam hal ini antara pemilik tanah warga wonorejo, pihak kelurahan, dan pihak panitia pembangunan tol. Fungsi Integratif ditandai dengan pihak Kepala Desa Wonorejo yang memberikan akses kepada setiap warga dalam berperan aktif dalam pembangunan desa. Sebagai upaya peningkatan pembangunan desa, pihak kelurahan telah memberikan wadah Melalui LPMP dan LPMD. Melalui lembaga ini kerjasama antar setiap individu di masyarakat dengan pihak kelurahan sebagai pemangku kepentingan di desa dapat terlaksana. Proses komunikasi organisasi yang dilakukan oleh aparatur desa Wonorejo meliputi proses komunikasi ke bawah, keatas, dan horizontal. Persepsi masyarakat terhadap komunikasi organisasi khususnya terhadap sosialisasi program desa kepada masyarakat secara umum adalah baik.Partisipasi masyarakat sangat diperlukan terutama dalam mengidentifikasi permasalahan pembangunan yang ada sehingga nantinya pembangunan yang akan dilaksanakan benar-benar merupakan kebutuhan dari masyarakat.
Dalam penelitian ini bagi pembangunan desa ada beberapa hal yang perlu di cermati kaitannya dengan manajemen konflik. Fungsi komunikasi organisasi yang diaksanakan pemerintah Desa Wonorejo dalam sosialisasi pembangunan dan sosialisasi penggantian tanah warga belum nampak manajemen reputasi serta resolusi konflik di dalam memberikan edukasi langsung kepada warga masyarakat desa.Bagi penelitian selanjutnya di harapkan muncul wacana baru dalam hal pembangunan desa berkaitan dengan isu-isu sensitif yang memicu hadirnya sebuah konflik baru di masyarakat.

\section{UCAPAN TERIMAKASIH (Optional)}

Terima kasih kami haturkan kepada pihak-pihak yang telah membantu pelaksanaan penelitian ini :

Kemenristekdikti melalui anggaran penelitian Penelitian Dosen Pemula Tahun Anggaran 2017.

Ir. Suci Purwandari, MM sebagai Direktur Politeknik Indonusa Surakarta yang telah mendukung dengan adanya sarana prasarana penelitian.

UPPM Politeknik Indonusa Surakarta yang telah membimbing dan membantu dalam pelaksanaan penelitian ini.

Pemerintah Desa Wonorejo Kecamatan Gondangrejo sebagai narasumber dalam penelitian ini. 
A. Anditha Sari \& Jahid Syaifullah, Perilaku Komunikasi Organisasi dalam Sosialisasi Program Kerja

\section{DAFTAR PUSTAKA}

Bungin. B. (2006) Sosiologi Komunikasi; Teori, Paradigma, Dan Diskursus Teknologi Komunikasi Di Masyarakat. Jakarta: Kencana Preda Group.

Danim, S. (2004). Motivasi Kepemimpinan \& Efektivitas Kelompok. Jakarta: PT Rineka Cipta.

Effendy, O U. (1981). Dimensi-Dimensi Komunikasi, Bandung, hak

Pawito. (2007). Penelitian Komunikasi Kualitatif. Yogyakarta: LkiS

Stephen, P.R. (2006). Prinsip-Prinsip Perilaku Organisasi Edisi Kelima. Jakarta:Penerbit Erlangga.
Sugiyono. 2010. Metode Penelitian Pendidikan Pendekatan Kuantitatif, kualitatif, dan R\&D. Bandung: Alfabeta

Surat Edaran bersama Menteri Negara Perencanaan Pembangunan Nasional/ Kepala Bappenas dan Menteri Dalam Negeri Nomor: 1181/M.PPN/02/2006 Tentang Petunjuk Teknis Penyelenggaraan Musyawarah Perencanaan Pembangunan Tahun 2006

Undang-Undang Nomor 6 Tahun 2014

Undang-Undang Nomor 23 Tahun 2014 